\title{
PERTANGGUNGJAWABAN PEJABAT PEMERINTAHAN DALAM TINDAKAN DISKRESI PASCA BERLAKUNYA UNDANG-UNDANG NO. 30 TAHUN 2014 TENTANG ADMINISTRASI PEMERINTAHAN
}

\author{
Oleh:
}

\author{
I Gusti Ayu Apsari Hadi ${ }^{1}$
}

Fakultas Hukum dan Ilmu Sosial Universitas Pendidikan Ganesha

\begin{abstract}
Abstrak
Negara Hukum Modern yang dikenal sebagai Welfare State menitikberatkan pada upaya pemerintahnya dalam usaha mensejahterakan masyarakat.Konsekuensi utama dalam pelaksanaan Welfare State ialah intervensi Pemerintah yang cukup luas terhadap aspek kehidupan masyarakat dan pelaksanaan diskresi (freies ermessen). Permasalahan hukum yang dibahas dalam penelitian ini yaitu: 1. Bagaimana batasan dalam penggunaan diskresi terhadap pengambilan keputusan pejabat pemerintahan?; dan 2. Bagaimana pertanggungjawaban hukum pejabat pemerintahan yang melakukan diskresi pasca berlakunya UU No. 30 Tahun 2014 tentang Administrasi Pemerintahan (UU Administrasi Pemerintahan)? Penelitian ini menggunakan metode penelitian hukum normatif yang mencakup penelitian terhadap asas-asas hukum, khususnya asas diskresi dengan pendekatan perundang-undangan.Penelitian ini bertujuan untuk mengetahui adanya bentuk pertanggungjawaban dari tindakan diskresi yang dilakukan oleh pejabat pemerintahan semenjak diatur dalam UU Administrasi Pemerintahan. Hasil penelitian menunjukkan berdasar UU Administrasi Pemerintahanmaka penggunaan diskresi wajib memperoleh persetujuan kepada pejabat atasannya.Pasal 24 UU Administrasi Pemerintahan menegaskan bahwa kewenangan diskresi oleh Pejabat Pemerintahan hanya dapat dilakukan dalam hal tertentu di mana perundang-undangan memberikan suatu pilihan, peraturan perundang-undangan yang berlaku tidak mengaturnya, ketidakjelasan peraturan perundang-undangan sehingga multitafsir, serta adanya stagnasi pemerintahan yakni menyangkut hajat hidup orang banyak.
\end{abstract}

Kata Kunci: Pertanggungjawaban, Pejabat Pemerintahan, Diskresi, Freies Ermessen.

\section{Abstract}

The modern Rule of Lawwhich are known as Welfare State emphasizes its government's efforts to create society welfare. The main consequencein implementingthe Welfare State is the broad intervention of governmenttowardsthe life of its societyand the discretion implementation (freies ermessen). The legal problems raised in this study are: 1. What are the limitationsin the use of discretion against the government's decision?; and 2. What are the government's responsibility who implementeddiscretion after the enforcement of Law No. 30 of 2014 on Government Administration (Government Administration Law)? This study uses normative legal research method which covers research on legal principles, specifically the discretionary principles by using statute approach. This study aims to determine the formof responsibility upon the implementation of discretion performed by the government after the enforcement ofGovernment Administration Law. The result shows that according to Government Administration Law. The result shows that according to Law No. 30 of 2014 the using of discretionary act shall obtained approval to its superior officer in the government. Article 24 of the Governmant Administration Law defines that discretion authority of the official of the government may be executedonly in certain cases where the legislation provides an options for that, the legislationdoes not regulate it,unclear legislations which lead to multiple interpretations, and government stagnation that concerns the livelihood of many people.

Keywords: Responsibility, Government Official, Discretion, Freies Ermessen.

\section{Pendahuluan}

\subsection{Latar Belakang}

Menurut teori kenegaraan, terdapat dua tipe negara yakni negara penjaga malam (nachtwakersstaat) dan negara kesejahteraan (welfare state). Jika negara penjaga malam lebih menekankan pada perwujudan kesejahteraan masyarakat tergantung pada masyarakatnya

1 I Gusti Ayu Apsari Hadi adalah Dosen Jurusan Hukum Fakultas Hukum dan Ilmu Sosial Universitas Pendidikan Ganesha. Korespodensi dengan penulis melalui email: apsari.hadi@undiksha.ac.id 
sendiri, yang mana fungsi negara lebih pasif hanya dituntut menciptakan situasi yang dapat melancarkan terciptanya kesejahteraan tersebut. Sedangkan negara dengan tipe kesejahteraan menuntut adanya peran aktif dari negara dalam menciptakan kesejahteraan rakyat.

Negara dengan tipe Welfare state yang menitikberatkan pada pemerataan kesejahteraan masyarakat diwujudkan misalnya dengan peraturan perijinan, penciptaan kebijaksanaan lewat deregulasi dalam bidang-bidang tertentu, dan sebagainya. ${ }^{2}$ Keseluruhan hal tersebut memerlukan peran serta aparat pemerintah sebagai salah satu upaya untuk mendukung terwujudnya kesejahteraan rakyat. Peran serta pemerintah diwujudkan melalui perbuatan pemerintah yang mencakup tindakan-tindakan dari satu alat administrasi negara yang meliputi juga perbuatan atau hal-hal yang berada di luar lapangan hukum tata pemerintahan, seperti keamanan, peradilan, dan sebagainya dengan maksud menimbulkan akibat hukum dalam bidang hukum administrasi negara.

Dalam melaksanakan tugas menyelenggarakan kepentingan umum, pemerintah banyak melakukan kegiatan atau perbuatan-perbuatan yang secara garis besarnya dibedakan ke dalam dua golongan, yakni³:

1. Golongan Perbuatan Hukum (Rechtshandelingen), dapat berupa:

a. Perbuatan hukum menurut hukumpublik, dibagi menjadi dua: Perbuatan Hukum Publik Bersegi Satu dan Perbuatan Hukum Publik Bersegi Dua. Akan tetapi, perbuatan hukum publik tidak ada yang bersegi dua, karena pada umumnya berasal dari pemerintah dan bersifat paksaan. Begitu pula sebaliknya pada perbuatan hukum privat tidak ada yang bersegi satu karena selalu akan ada kehendak dari kedua belah pihak. ${ }^{4}$

b. Perbuatan hukum menurut hukum privat (sipil), merupakan perbuatan hukum yang sering dilakukan oleh aparat pemerintah dengan subyek hukum lain berdasarkan hukum privat seperti sewa-menyewa, jual-beli, dan sebagainya. Contoh, Bupati mengadakan perjanjian dengan pihak swasta untuk melaksanakan proyek pembangunan yang diatur oleh hukum perjanjian (hukum perdata).

2. Golongan Perbuatan Yang Bukan Perbuatan Hukum (Feitelijkehandelingen). Dalam hal ini perbuatan yang bukan perbuatan hukum tidak relevan jadi tidak akan dibahas lebih lanjut.

Dari tipe negara kesejahteraan, dua konsekuensi utama yang dihadapi dalam pelaksanaannya ialah intervensi Pemerintah yang cukup luas terhadap aspek kehidupan masyarakat dan

2 Muchsan.2000.Sistem Pengawasan Terhadap Perbuatan Aparat Pemerintah dan Peradilan Tata Usaha Negara di Indonesia. Penerbit: Liberty, Yogyakarta, h.7.

3 S.F. Marbun. 2012. Hukum Administrasi Negara I. Penerbit: FH UII Press, Yogyakarta, h. 149.

4 Muchsan, disampaikan dalam kuliah "Hukum Tata Usaha Negara” Program Magister Hukum Kenegaraan pada 18 Oktober 2013 di Universitas Gadjah Mada, Yogyakarta. 
juga pelaksanaan diskresi atau freies ermessen (Jerman).Tindakan diskresi memungkinkan pejabat pemerintahan berhak untuk melakukan tindakan tertentu dalam mengatasi persoalan konkret yang dihadapi pemerintahan ketika perundang-undangan yang memberikan pilihan, tidak mengatur, tidak lengkap atau tidak jelas maupun terjadi stagnasi pemerintahan. ${ }^{5}$ Diskresi pun telah diatur dalam Undang-Undang No. 30 Tahun 2014 tentang Administrasi Pemerintahan. Akan tetapi ada kalanya pejabat pemerintahan masih ragu akan pengambilan keputusan dengan menggunakan asas freies ermessen tersebut karena takut akan adanya pertanggungjawaban hukum nantinya. Apabila tindakan yang dilakukan pejabat pemerintahan tersebut telah dibenarkan secara hukum administrasi, semestinya hal tersebut juga tidak akan melanggar aturan hukum lain apalagi sampai diproses secara hukum dan bahkan seolah-olah telah terjadi kriminalisasi.

Berdasarkan latar belakang masalah yang telah penulis ungkapkan sebelumnya, maka penulis tertarik meneliti masalah hukum ini dalam bentuk jurnal ilmiah yang berjudul : "PERTANGGUNGJAWABAN PEJABAT PEMERINTAHAN DALAM TINDAKAN DISKRESI PASCA BERLAKUNYA UNDANG-UNDANG NO. 30 TAHUN 2014 TENTANG ADMINISTRASI PEMERINTAHAN".

\subsection{Rumusan Masalah}

Berdasarkan pemaparan latar belakang masalah yang telah diungkapkan sebelumnya, rumusan masalah yang akan dibahas pada penelitian ini yakni berkaitan dengan :

1. Bagaimana batasan dalam penggunaan diskresi terhadap pengambilan keputusan pejabat pemerintahan?

2. Bagaimana pertanggungjawaban hukum pejabat pemerintahan yang melakukan diskresi pasca berlakunya UU No. 30 Tahun 2014 tentang Administrasi Pemerintahan?

\section{METODE PENELITIAN}

\subsection{Tujuan Penelitian}

Tujuan penelitian ini dimaksudkan untuk mengetahui bentuk pertanggungjawaban dari tindakan diskresi yang dilakukan oleh pejabat pemerintahan semenjak berlakunya UU No. 30 Tahun 2014 tentang Administrasi Pemerintahan. Sehingga dengan adanya hal tersebut memberikan penjelasan lebih lanjut tentang bilamana seorang pejabat dapat melakukan tindakan diskresi dalam setiap kebijakan yang akan ditempuh. Penelitian ini juga akan menegaskan kembali akibat hukum bagi pejabat dalam pemberian diskresi serta bentuk pertanggungjawaban pejabat yang mengeluarkan kebijakan yang bukan atas wewenangnya sehingga menyimpang dari apa yang tertuang dalam UU No. 30 Tahun 2014 tentang Administrasi Pemerintahan.

5 Pasal 1 angka 9 Undang-Undang No. 30 Tahun 2014 tentang Administrasi Pemerintahan 
KERTHA PATRIKA

Volume 39, Nomor 1, April 2017

\subsection{Metode Penelitian}

Penelitian ini merupakan jenis penelitian hukum normatif.Pada penelitian hukum normatif mencakup penelitian terhadap asas-asas hukum, penelitian terhadap sistematika hukum, sinkronisasi hukum, dan sebagainya. ${ }^{6}$ Salah satunya adalah terhadap asas-asas hukum yang pada penelitian ini terkait dengan diberlakukannya asas diskresi sebagaimana diatur dalam Pasal 24 UU No. 30 Tahun 2014.Penelitian ini mempergunakan pendekatan perundang-undangan (The Statute Approach) dan pendekatan analisis konsep hukum (Analitical and Conceptual Approach). Sumber bahan hukum yang dipergunakan adalah bahan hukum primer yang bersumber dari peraturan hukum nasional meliputi peraturan perundang-undangan yang relevan sesuai dengan hierarkinya mulai dari Undang-Undang Dasar Negara Republik Indonesia Tahun 1945, Undang-Undang, dan sebagainya. Sumber bahan hukum yang lain adalahbahan hukum sekunder yaitu semua literatur-literatur hukum yang relevan, mulai dari buku teks, laporan penelitian, artikel dalam jurnal hukum, diktat perkuliahan, dan lain-lain.

\section{PEMBAHASAN}

\subsection{Batasan Diskresi dalam Pengambilan Keputusan Tata Usaha Negara}

Diskresi atau yang dikenal juga dengan freies ermessen berasal dari kata frei yang artinya bebas, lepas, tidak terikat, dan merdeka. Freies artinya orang yang bebas, tidak terikat, dan merdeka. Sedangkan Ermessen artinya mempertimbangkan, menilai, menduga, dan memperkirakan. Jadi Freies Ermessen berarti orang yang memiliki kebebasan untuk menilai, menduga, dan mempertimbangkan sesuatu. Freies Ermessen (diskresionare) kemudian digunakan dalam bidang pemerintahan sebagai salah satu sarana yang memberikan ruang bergerak bagi pejabat atau badan-badan administrasi negara untuk melakukan tindakan tanpa harus terikat sepenuhnya pada undang-undang. ${ }^{7}$

Beberapa ahli mendefinisikan diskresi diantaranya S. Prajudi Atmosudirjo yang mengartikan discretion (Inggris), discretionair (Prancis), freies ermessen (Jerman) sebagai kebebasan bertindak atau mengambil keputusan dari pejabat administrasi negara yang berwenang dan wajib menurut pendapat sendiri. ${ }^{8}$ Selanjutnya dijelaskan bahwa diskresi diperlukan sebagai pelengkap dari asas legalitas, tidak mungkin bagi Undang-Undang untuk mengatur segala macam posisi kasus dalam praktek kehidupan sehari-hari.Dengan demikian, inilah yang dapat digunakan aparat pemerintah untuk menembus legalitas produk hukum yang terkadang menemui kebuntuan, sepanjang demi kepentingan rakyat banyak.

Pendapat serupa juga diungkapkan SF Marbun dan Mahfud MD, freies ermessen, yaitu kewenangan yang sah untuk turut campur dalam kegiatan sosial guna melaksanakan tugastugas menyelenggarakan kepentingan umum itu; seperti memberi izin, melakukan pencabutan

6 A. Muktie Fajar dan Yulianto Ahmad.2009. Dualisme Penelitian Hukum Normatif dan Empiris. Penerbit: Pustaka Pelajar, Yogyakarta, h. 153.

7 Ridwan HR.2010. Hukum Administrasi Negara. Penerbit: Rajawali Pers, Jakarta, h. 177.

8 S. Prajudi Atmosudirjo. 1994. Hukum Administrasi Negara. Penerbit: Ghalia Indonesia, Jakarta, h. 82. 
hak, mendirikan rumah sakit, dan sebagainya. Tercakup dalam pengertian freies ermessen ialah membuat peraturan tentang hal-hal yang belum ada pengaturannya, atau mengimplementasikan peraturan yang ada sesuai kenyataan.Pencakupan yang demikian disebut discretionary power. $^{9}$

Di dalam kerangka negara hukum, diskresi merupakan sebuah tindakan tidak tanpa batas. Hal tersebut berarti terdapat unsur-unsur yang menentukan dapat diberlakukannya diskresi oleh pejabat pemerintah, yakni: ${ }^{10}$

a. Ditujukan untuk menjalankan tugas-tugas servis publik;

b. Merupakan sikap tindak yang aktif dari administrasi negara;

c. Sikap tindak itu dimungkinkan oleh hukum;

d. Sikap tindak itu diambil atas inisiatif sendiri;

e. Sikap tindak itu dimaksudkan untuk menyelesaikan persoalan-persoalan penting yang timbul secara tiba-tiba;

f. Sikap tindak itu dapat dipertanggungjawabkan baik secara moral kepada Tuhan Yang Maha Esa maupun secara hukum.

Konsekuensi logis adanya tindakan diskresi adalah di bidang perundang-undangan, yakni adanya penyerahan kekuasaan legislatif kepada Pemerintah sehingga dalam keadaan tertentu dan/atau dalam porsi dan tingkat tertentu Pemerintah dapat mengeluarkan peraturan perundangan tanpa persetujuan lebih dulu dari parlemen.Selain itu, pemerintah juga diberi kewenangan droit function yakni kekuasaan untuk menafsirkan suatu peraturan perundangundangan, namun bukan berarti pemerintah boleh berbuat sewenang-wenang.Pemerintah dilarang melakukan tindakan-tindakan yang bersifat detournement de pouvoir (melakukan sesuatu di luar tujuan kewenangan yang diberikan) atau onrechmatige overheidsdaad (perbuatan melawan hukum oleh penguasa) dan perbuatan tersebut dapat dituntut di muka hakim baik melalui peradilan administrasi negara maupun melalui peradilan umum. ${ }^{11}$

Bagi negara dengan tipe Welfare State, asas legalitas semata tidak akan mampu melayani kepentingan masyarakat sepenuhnya di tengah semakin berkembangnya persoalan-persoalan di bidang administrasi. Dapat diibaratkan masalah pengaturan lalu lintas oleh polisi. Apabila seorang polisi meminta pengendara untuk tetap berjalan walau sudah lampu merah, atau menutup sebagian ruas jalan dan mengalihkannya ke jalan lainnya hanya karena faktor kemalasan untuk beraktivitas, maka akibat dari diskresi yang dilakukan justru akan terjadi macet di wilayah lainnya. Dalam kondisi yang demikian, maka diskresi yang dilakukan oleh kepolisian tadi sangatlah tidak tepat, karena yang terjadi hanyalah pemindahan persoalan

9 SF. Marbun \& Mahfud MD. 2006. Pokok-pokok Hukum Administrasi Negara. Penerbit: Liberty, Yogyakarta, h. 46.

10 Ridwan HR, Op. Cit., h. 178.

11 SF. Marbun \& Mahfud MD, Op. Cit., h. 47. 
semata, memindahkan kemacetan dari yang seharusnya menjadi tanggung jawabnya, dipindahkan ke tempat lain dengan harapan agar si pelaku diskresi bisa terbebas dari masalah kemacetan. Justru diskresi dalam contoh tadi secara tidak langsung jauh dari cita-citanya untuk memberikan pelayanan umum.

Oleh sebab itu, batasan penggunaan diskresi ini menjadi sangat urgen dan mendesak. Menurut Muchsan pembatasan penggunaan freies ermessen adalah sebagai berikut: ${ }^{12}$

1. Penggunaan freies ermessen tidak boleh bertentangan dengan sistem hukum yang berlaku (kaidah hukum positif)

2. Penggunaan freies ermessen hanya ditujukan demi kepentingan umum.

Jika berbicara ilmu hukum administrasi negara, freies ermessen ini diberikan hanya kepada pemerintah atau administrasi negara baik untuk melakukan tindakan-tindakan biasa maupun tindakan hukum. Ketika freies ermessen diwujudkan dalam istrumen yuridis yang tertulis, ia dikenal sebagai peraturan kebijaksanaan. Pembuatan peraturan kebijaksanaan dalam hal ini menjadi kewenangan pemerintahan (eksekutif) untuk menjalankan fungsinya yakni membuat suatu keputusan (beschikking) meskipun hal tersebut belum diatur secara tegas.

Secara praktis kewenangan diskresioner administrasi negara yang kemudian diwujudkan dalam sebuah keputusan Tata Usaha Negara mengandung dua aspek pokok. Pertama, kebebasan menilai yang bersifat objektif adalah kebebasan menafsirkan mengenai ruang lingkup wewenang yang dirumuskan dalam peraturan dasar wewenangnya. Kedua, kebebasan menilai bersifat subjektif adalah kebebasan untuk menentukan sendiri dengan cara bagaimana dan kapan wewenang yang dimiliki administrasi negara itu dilaksanakan. Dengan adanya kebebasan yang mandiri dari pemerintah inilah menjadi dasar atas dikeluarkannya Keputusan bebas (discretionary decision atau Vrije beschikking).

Sebagaimana dengan diberlakukannya UU No. 30 Tahun 2014 tentang Administrasi Pemerintahan, pemberian diskresi yang dilakukan oleh pejabat pemerintahan diatur secara tegas di dalam pasal-pasalnya. Pembatasan diskresi bisa dilihat dalam Pasal 24 UU No. 30/2014 yang berbunyi :

Pejabat Pemerintahan yang menggunakan Diskresi harus memenuhi syarat :

a. $\quad$ sesuai dengan tujuan Diskresi sebagaimana dimaksud dalam Pasal 22 ayat (2);

b. tidak bertentangan dengan ketentuan peraturan perundang-undangan;

c. sesuai dengan AUPB;

d. berdasarkan alasan-alasan yang objektif;

e. tidak menimbulkan konflik kepentingan;

f. dilakukan dengan itikad baik.

12 Muchsan.1981. Beberapa Catatan tentang Hukum Administrasi Negara dan Peradilan Administrasi di Indonesia. Penerbit: Liberty, Yogyakarta, h. 28. 
Dari rumusan tersebut dengan cukup jelas memberi batasan bahwa Pejabat Pemerintahan yang melakukan diskresi wajib mempertimbangkan tujuan diskresi, peraturan perundang-undangan yang menjadi dasar diskresi, kebebasan berdasarkan penilaian objektif, sejauh mungkin dihindarkan dari konflik kepentingan, itikad baik, serta berpedoman pada Asas-Asas Umum Pemerintahan yang Baik (AUPB).

AUPB dapat dijadikan rambu-rambu bagi setiap Keputusan diskresi yang dikeluarkan Pejabat Pemerintahan, khususnya asas tidak menyalahgunakan kewenangan dan asas kepentingan umum.Kebijakan pemerintah akan dikategorikan sebagai kebijakan yang menyimpang jika di dalamnya ada unsur sewenang-wenang. Selain itu kebijakan dianggap menyimpang jika bertentangan dengan kepentingan umum.

Asas larangan menyalahgunakan kewenangan termasuk di dalam mengambil keputusan tidak boleh berdasarkan atas pertimbangan kepentingan pribadi atau tujuan lain selain maksud dan tujuan dalam wewenang yang diberikan kepada pejabat tersebut. Kepentingan pribadi maksudnya adalah semua kepentingan yang tidak hanya mendahulukan kepentingan pribadi sendiri, tetapi juga mendahulukan kepentingan keluarga, golongan, suku, agama tertentu, politik, ekonomi, gender, dalam mengambil keputusan. ${ }^{13}$ Dengan kata lain asas ini memberikan pemahaman agar pejabat pemerintahan tidak boleh bertindak atas sesuatu yang bukan wewenangnya (exces de pouvoir).

Asas kepentingan umum menurut UU No. 30/2014 mengandung unsur: (1) mendahulukan kesejahteraan dan kemanfaatan umum; (2) dengan cara yang aspiratif, akomodatif, selektif, dan tidak diskriminatif. Asas kepentingan umum juga terdapat dalam UU No. 23 Tahun 2014 tentang Pemerintahan Daerah Pasal 58 yang menyatakan, Penyelenggaraan Pemerintahan Daerah berpedoman pada asas penyelenggaraan pemerintahan negara yang terdiri atas kepentingan umum. Selanjutnya, unsur-unsur yang termuat dalam asas kepentingan umum menurut UU Pemda adalah: (1) mendahulukan kesejahteraan umum; (2) dengan cara yang aspiratif, akomodatif, dan selektif. Dengan demikian, terdapat kesamaan unsur-unsur sebagai pembentuk asas kepentingan umum.Hanya saja di dalam UU Administrasi Pemerintahan terdapat tambahan unsur "tidak diskriminatif". Secara prinsipiil, asas kepentingan umum sangat penting posisinya dalam penyelengaraan pemerintahan.Prinsip ini bagi aparatur pemerintah sebagai pelayan masyarakat, harus mendahulukan kesejahteraan umum dengan cara memahami dan menampung harapan dan keinginan masyarakat secara cermat. ${ }^{14}$ Dalam hubungan ini kebijakan yang dibuat adalah untuk menjamin terpenuhinya kebutuhan masyarakat, bukan kepentingan sekelompok orang ataupun ada kaitan keluarga, agama, dan sebagainya.

UU No. 30/2014 juga memberi penegasan batas ruang lingkup penggunaan diskresi yang diatur dalam Pasal 23, sebagai berikut :

\footnotetext{
13 S.F. Marbun, Op. Cit., h. 125.

14 Lembaga Kajian \& Advokasi Independensi Peradilan, Penjelasan Hukum Asas-Asas Umum Pemerintahan Yang Baik (AUPB) Hukum Administrasi Negara, http://leip.or.id/wp-content/uploads/2016/05/Penjelasan-Hukum-Asas-Asas-Umum-Pemerintahan-yang-Baik-Hukum-Administrasi-Negara.pdf, diakses tanggal 22 Maret 2017.
} 
Diskresi Pejabat Pemerintahan meliputi:

a. pengambilan Keputusan dan/atau Tindakan berdasarkan ketentuan peraturan perundang-undangan yang memberikan suatu pilihan Keputusan dan/atau Tindakan;

b. pengambilan Keputusan dan/atau Tindakan karena peraturan perundang-undangan tidak mengatur;

c. pengambilan Keputusan dan/atau Tindakan karena peraturan perundang-undangan tidak lengkap atau tidak jelas; dan

d. pengambilan Keputusan dan/atau Tindakan karena adanya stagnasi pemerintahan guna kepentingan yang lebih luas.

Berdasarkan isi pasal di atas, dapat disimpulkan bahwa penggunaan kewenangan diskresi oleh Pejabat Pemerintahan hanya dapat dilakukan dalam hal tertentu di mana perundangundangan memberikan suatu pilihan, peraturan perundang-undangan yang berlaku tidak mengaturnya, ketidakjelasan peraturan perundang-undangan sehingga multitafsir, serta adanya stagnasi pemerintahan yakni menyangkut hajat hidup orang banyak, seperti: bencana alam, wabah penyakit, konflik sosial, kerusuhan, pertahanan dan kesatuan bangsa. ${ }^{15}$

Pembatasan tindakan diskresi yang diatur dalam UU No. 30 Tahun 2014 setidaknya menegaskan penggunaan freies ermessen sebagai suatu norma yang mengikat sehingga sudah cukup untuk menghindari adanya penyalahgunaan wewenang (detournement de pouvoir) dan perbuatan sewenang-wenang oleh pejabat pemerintahan. Tujuan utama dari dituangkannnya diskresi dalam UU No. 30/2014 ialah semata-mata menciptakan dan menunjang kepastian hukum serta jaminan perlindungan hukum di bidang administrasi negara khususnya bagi warga negara.

\subsection{Pertanggungjawaban Hukum Pejabat Pemerintahan yang Melakukan Diskresi Hukum Pasca Berlakunya UU No. 30 Tahun 2014 tentang Administrasi Pemerintahan}

Jika berbicara mengenai pertanggungjawaban, maka diskresi akan terkait dengan permasalahan subyek yang memiliki kewenangan membuat diskresi. Dalam hal ini maka subyek yang berwenang untuk membuat suatu diskresi adalah pejabat pemerintahan.Menurut ketentuan Pasal 1 angka 3 yang berbunyi, "Badan dan/atau Pejabat Pemerintahan adalah unsur yang melaksanakan Fungsi Pemerintahan, baik di lingkungan pemerintah maupun penyelenggara negara lainnya". Sehubungan dengan hal tersebut yang dimaksud pejabat pemerintahan di sini ialah dalam pengertian sempit, yaitu eksekutif.

Alasan utama yang dikedepankan sehubungan dengan hal di atas adalah bahwa eksekutiflah yang lebih banyak bersentuhan dengan masalah pelayanan publik sehingga diskresi hanya ada di lingkungan pemerintahan (eksekutif). Bentuk-bentuk sederhana dari keputusan administrasi di luar peraturan perundang-undangan yang dapat dilihat dalam contoh kehidupan sehari-hari adalah memo yang dikeluarkan oleh pejabat, pengumuman, surat keputusan (SK), surat penetapan, dan lain-lain.

15 Penjelasan Pasal 23 huruf d Undang-Undang No. 30 Tahun 2014. 
Menurut Muchsan, pelaksanaan diskresi oleh aparat pemerintah (eksekutif) dibatasi oleh 4 (empat) hal, yaitu:

a. Apabila terjadi kekosongan hukum;

b. Adanya kebebasan interprestasi;

c. Adanya delegasi perundang-undangan;

d. Demi pemenuhan kepentingan umum.

Sebenarnya beberapa pendapat telah mengemukakan tentang penting atau tidaknya pertanggungjawaban atas tindakan diskresi yang dilakukan oleh pejabat administrasi negara.Pakar Hukum Tata Negara Universitas Indonesia, Bintan R. Saragih berpendapat bahwa diskresi tidak perlu diatur atau dibatasi karena sudah ada pertanggungjawabannya sendiri baik secara moral maupun hukum. Ditambahkan lagi oleh Prof. Bintan R. Saragih, bahwa pengaturan mengenai diskresi pejabat hanya lazim digunakan pada sistem parlementer, sementara sistem presidensial lebih menggunakan kebiasaan. ${ }^{16}$

Guru Besar Ilmu Hukum Pidana Universitas Indonesia, Topo Santoso, mengungkapkan hukum pidana semestinya tidak "tutup mata" terhadap diskresi yang dilakukan oleh pejabat pemerintahan. Jika tindakan pejabat tersebut telah dibenarkan dalam hukum administrasi negara, semestinya hukum pidana dapat memperhatikan tindakan tersebut sebagai tindakan yang tidak melanggar hukum dan harus mendapat perlindungan hukum. Selama ini, banyak pejabat yang ragu mengeluarkan kebijakan tertentu yang belum diatur dalam perundang-undangan karena takut dianggap melanggar hukum.Padahal, secara hukum administrasi kebijakannya itu dapat dianggap benar, selama kebijakan tersebut bukanlah untuk kepentingan pribadi melainkan untuk kepentingan publik. ${ }^{17}$

Untuk mengetahui siapa yang bertanggung jawab dalam penyelenggaraan tugas-tugas pemerintahan, kita harus mengacu pada pengertian pertanggungjawaban dalam ensiklopedi administrasi, responsibility adalah keharusan seseorang untuk melaksanakan secara selayaknya apa yang telah diwajibkan kepadanya. Disebutkan bahwa pertanggungjawaban mengandung makna; meskipun seseorang mempunyai kebebasan dalam melaksanakan sesuatu tugas yang dibebankan kepadanya, namun ia tidak dapat membebaskan diri dari hasil atau akibat kebebasan perbuatannya dan ia dapat dituntut untuk melaksanakan secara layak apa yang diwajibkan kepadanya. ${ }^{18}$ Pertanggungjawaban pejabat pemerintahan dalam makna ini bahwa beban tanggung jawab tetap akan ditujukan kepada setiap subjek hukum yang melanggar hukum tidak peduli apakah subjek hukum itu seseorang sebagai pribadi, maupun pemerintah.

${ }^{16}$ Muhammad Ikhwan, Penerapan Asas Diskresi Dalam Pembuatan Keputusan Tata Usaha Negara, http://studihukum. blogspot.co.id/2010/10/penerapan-asas-diskresi-dalam-pembuatan.html, diakses tanggal 1 April 2017

17 Ibid.

${ }^{18}$ Ridwan HR, Op. Cit., h. 338. 
Dalam konteks ini, tanggung jawab akan tertuju pada pejabat pemerintahan yang melaksanakan urusan pemerintahan yang melakukan tindakan diskresi. Sesuai dengan prinsip "deen bevoegheid zonder verantwoordenlijkheid" yakni tidak ada kewenangan tanpa pertanggungjawaban maka setiap penggunaan wewenang oleh pejabat selalu disertai dengan tanggung jawab. ${ }^{19}$ Karena wewenang itu melekat pada jabatan, namun dalam implementasinya dijalankan oleh manusia selaku wakil atau fungsionaris jabatan, maka siapa yang harus memikul tanggung jawab hukum ketika terjadi penyimpangan harus dilihat secara kasuistik karena tanggung jawab itu dapat berupa tanggung jawab jabatan dan dapat pula berupa tanggung jawab dan tanggung gugat pribadi.

\section{a. Tanggung Jawab Jabatan}

Apabila perbuatan hukum seseorang untuk dan atas nama jabatan, maka pertanggungjawabannya terletak pada jabatan. Jika ada ganti rugi atau denda, maka dibebankan pada APBN atau APBD.Tanggungjawab jabatan ini berkenaan dengan keabsahan tindakan hukum pemerintahan yang dilakukan oleh pejabat untuk dan atas nama jabatan (ambtshalve). Meskipun kewenangan itu melekat pada jabatan yang membawa konsekwensi melekatnya tanggung jawab pada jabatan yang bersangkutan, namun dapat saja dalam pelaksanaan kewenangan itu tanggung jawabnya dibebankan kepada pribadi (in persoon) pejabat. ${ }^{20}$

\section{b. Tanggung Jawab Pribadi}

Tanggung jawab pribadi berkaitan dengan maladministrasi dalam penggunaan wewenang maupun pelayanan umum.Maladministrasi berasal dari bahasa Latin malum (jahat, buruk, jelek) dan administrare (to manage, mengurus, atau melayani). Maladministrasi berarti pelayanan yang buruk atau jelek. Jadi apabila pemerintah dalam memproduksi keputusan salah dalam mempertimbangkan kepentingan umum sehingga keputusan yang dibuatnya lebih banyak merugikan masyarakat, di sinilah terjadi perbuatan penguasa yang sewenangwenang (maladministratif).

Terhadap perbuatan maladministrasi terdapat beberapa upaya hukum yang dapat ditempuh, yakni sebagai berikut: ${ }^{21}$

1. Jalur Keberatan Administratif, merupakan upaya hukum yang ditujukan kepada aparat pemerintah yang setingkat lebih tinggi kedudukannya yang memproduksi keputusan TUN. Tidak ada hukum acara hanya berdasarkan kebijakan atau kebiasaan. Keputusannya juga bersifat tidak mengikat, lebih mengacu pada lembaga perdamaian.

2. Banding Administratif, merupakan upaya hukum yang ditujukan ke Peradilan Semu. Di Indonesia ada beberapa Peradilan Semu seperti: Peradilan Pajak (Menkeu), Peradilan Perburuhan, Badan Pertimbangan Kepegawaian.

\footnotetext{
19 Julista Mustamu, Diskresi dan Tanggungjawab Administrasi Pemerintahan, Jurnal Sasi, 2011, Vol.17, h. 6.

20 Ibid.

${ }^{21}$ Pasal 48 Undang-Undang No. 5 Tahun 1986 tentang Peradilan Tata Usaha Negara.
} 
Perbedaan peradilan Semu dengan Peradilan Murni dapat ditinjau dari unsur-unsur peradilan yaitu:

a. Ada sengketa hukum, hakekatnya ialah perbedaan pendapat, minimal antara dua pihak tentang hak dan atau kewajiban.

b. Ada hukum materiil yang diterapkan misalnya dalam jual beli maka yang dipakai BW, dsb.

c. Ada hukum formil (hukum acara), mulai dari tahap pendaftaran sampai vonis dan eksekusi.

d. Ada pihak ketiga yang berhak dan berwenang mengadili, diartikan ialah pihak yang tidak termasuk penggugat atau tergugat (PTUN) atau terdakwa dan jaksa (Pidana), sedangkan pihak ketiga disini ialah hakim.

Apabila keempat unsur tersebut terpenuhi maka disebut Peradilan Murni, akan tetapi jika satu atau lebih tidak terpenuhi maka disebut Peradilan Semu.

3. Gugat Administratif, upaya hukum yang ditujukan kepada Peradilan Murni.

Dapat dikatakan bahwa setiap penyelenggaraan urusan pemerintahan yang di dalamnya ada unsur maladministrasi dan merugikan warga negara, maka tanggung jawab dan tanggung gugatnya dibebankan kepada pribadi orang yang melakukan tindakan maladministrasi tersebut.

Selanjutnya dalam UU No. 30/2014 tentang Administrasi Pemerintahan menyatakan bahwa penggunaan diskresi wajib memperoleh persetujuan kepada pejabat atasannya. Dalam artian, bahwa pertanggungjawaban Badan/Pejabat Administrasi Pemerintahan terhadap penggunaan diskresi yang tidak hanya bersifat pasif dalam arti menunggu adanya gugatan dari masyarakat, melainkan adanya kewajiban yang sifatnya melekat pada kewenangan yang menjadi dasar adanya diskresi itu sendiri. Selain itu di dalam penjelasannya juga menyatakan bahwa pertanggungjawaban kepada atasan dilaksanakan dalam bentuk tertulis dengan memberikan alasan-alasan pengambilan keputusan diskresi. Meskipun ketentuan mengenai sanksi apabila keharusan melapor kepada atasannya tidak dilakukan masih belum diatur dengan tegas dalam undang-undang ini. Hal tersebut bisa saja akan mengakibatkan keputusan dari pejabat yang bersangkutan tidak sah dan mengganggu pelayanan umum.

Adapun pertanggungjawaban hukum pejabat yang menerbitkan diskresi harus dibedakan dari segi administrasi, perdata, dan pidana. Dari segi administrasi, keputusan diskresi wajib dilaporkan secara tertulis kepada atasan langsung pejabat yang menerbitkan keputusan diskresi. Atasan pejabat apabila dirasa keputusan diskresi tersebut tidak dapat dibenarkan dari segi hukum dan kebijakan, maka atasan yang menerbitkan keputusan diskresi harus memerintahkan diskresi tersebut dicabut. ${ }^{22}$

${ }^{22}$ Lutfil Ansori, Diskresi Pertanggungjawaban Pemerintah Dalam Penyelenggaraan Pemerintahan, Jurnal Yuridis, 2015, Vol.2, h. 12. 
Keputusan diskresi yang menimbulkan akibat pidana, harus menjadi tanggung jawab Pejabat Pemerintahan yang bersangkutan dan Keputusan diskresi yang menimbulkan akibat pada kerugian perdata bagi perorangan, kelompok masyarakat, atau organisasi menjadi tanggung jawab pejabat pemerintahan yang menetapkan diskresi. Sedangkan keputusan diskresi yang diakibatkan oleh kelalaian pejabat pemerintahan yang dapat merugikan keuangan negara/ daerah serta bertentangan dengan kebijakan negara menjadi tanggung jawab pribadi (pejabat pemerintahan) yang tidak dapat dibebankan kepada negara baik perdata maupun pidana. ${ }^{23}$

Di dalam UU No. 30/2014 Pasal 75 ayat (1) menyebutkan, "Warga Masyarakat yang dirugikan terhadap Keputusan dan/atau Tindakan dapat mengajukan Upaya Administrasi kepada Pejabat Pemerintahan atau Atasan Pejabat yang menetapkan dan/atau melakukan Keputusan dan/atau Tindakan”. Dilanjutkan dalam Pasal 75 ayat (2), Upaya Administrasi yang dimaksud terdiri atas: (a). keberatan; dan (b). banding. Melalui ketentuan tersebut apabila masyarakat merasa kepentingannya dirugikan oleh keputusan diskresi, dapat mengajukan keberatan kepada pejabat yang menerbitkan keputusan diskresi. Terhadap keberatan masyarakat tersebut, pejabat yang bersangkutan wajib menjawabnya.Apabila atas jawaban tersebut masyarakat masih belum puas maka dapat mengajukan banding administrasi kepada atasan langsung pejabat pemerintahan yang menerbitkan diskresi.Terhadap pengajuan banding administrasi, atasan pejabat pemerintahan wajib pula menjawab pengajuan tersebut.Begitu pula dalam hal warga masyarakat tidak menerima atas penyelesaian banding oleh atasan pejabat, warga dapat mengajukan gugatan ke pengadilan. ${ }^{24}$

Dengan demikian undang-undang ini memungkinkan warga masyarakat untuk mengajukan keberatan dan banding terhadap keputusan dan tindakan Administrasi Pemerintahan yang merugikan kepentingan masyarakat. Selain itu terhadap keputusan dan/atau tindakan diskresi yang dilakukan oleh pejabat pemerintahan yang memang diperuntukkan bagi kepentingan umum akan dapat dipertanggungjawabkan sesuai dengan ketentuan yang diatur dalam UU No. 30/2014.

\section{PENUTUP}

\subsection{Kesimpulan}

1. Di dalam kerangka negara hukum, diskresi merupakan sebuah tindakan tidak tanpa batas. Kewenangan diskresi yang kemudian diwujudkan dalam sebuah keputusan Tata Usaha Negara mengandung dua aspek pokok. Pertama, kebebasan menilai yang bersifat objektif adalah kebebasan menafsirkan mengenai ruang lingkup wewenang yang dirumuskan dalam peraturan dasar wewenangnya. Kedua, kebebasan menilai bersifat subjektif adalah kebebasan untuk menentukan sendiri dengan cara bagaimana dan kapan wewenang yang

\footnotetext{
${ }^{23}$ Ibid.

${ }^{24}$ Pasal 76 ayat (3) Undang-Undang No. 30/2014.
} 
dimiliki administrasi negara itu dilaksanakan. Berlakunya UU No. 30/2014 Pasal 24 menegaskan tentang pembatasan kewenangan diskresi oleh Pejabat Pemerintahan hanya dapat dilakukan dalam hal tertentu di mana perundang-undangan memberikan suatu pilihan, peraturan perundang-undangan yang berlaku tidak mengaturnya, ketidakjelasan peraturan perundang-undangan sehingga multitafsir, serta adanya stagnasi pemerintahan yakni menyangkut hajat hidup orang banyak.

2. Pertanggungjawaban atas tindakan diskresi yang dilakukan oleh pejabat administrasi negara tidak hanya bersifat pasif dalam arti menunggu adanya gugatan dari masyarakat, melainkan adanya kewajiban yang sifatnya melekat pada kewenangan yang menjadi dasar adanya diskresi itu sendiri. Adapun pertanggungjawaban hukum pejabat yang menerbitkan diskresi harus dibedakan dari segi administrasi, perdata, dan pidana. Dari segi administrasi, keputusan diskresi wajib dilaporkan secara tertulis kepada atasan langsung pejabat yang menerbitkan keputusan diskresi. Keputusan diskresi yang menimbulkan akibat pidana, harus menjadi tanggung jawab Pejabat Pemerintahan yang bersangkutan dan Keputusan diskresi yang menimbulkan akibat pada kerugian perdata bagi perorangan, kelompok masyarakat, atau organisasi menjadi tanggung jawab pejabat pemerintahan yang menetapkan diskresi. Di dalam UU No. 30/2014 juga mengatur warga masyarakat yang dirugikan terhadap Keputusan dan/atau Tindakan dapat mengajukan Upaya Administrasi kepada Pejabat Pemerintahan atau Atasan Pejabat yang menetapkan dan/atau melakukan Keputusan dan/atau Tindakan, yakni berupa keberatan dan banding.

\subsection{Saran}

1. Agar setiap pejabat pemerintah dalam membuat sebuah kebijakan yang mengatasnamakan kepentingan umum lebih memperhatikan kembali ketentuan yang tertuang dalam UU Administrasi Pemerintahan. Sehingga ke depan dapat meminimalisir ketidakpuasan masyarakat terhadap produk hukum yang dikeluarkan pemerintah. Hendaknya pemerintah tetap berpegang pada unsur-unsur tindakan yang dikategorikan sebagai tindakan diskresi sehingga tetap berjalan dalam koridor hukum yang sesuai.

2. Diharapkan pejabat pemerintah mampu mengetahui setiap resiko atas kebijakan yang diambilnya, khususnya dalam melakukan tindakan diskresi yang kini telah diatur lebih tegas dalam UU Administrasi Pemerintahan. Sehingga nantinya mampu mencermati yang mana tindakan yang patut dan sesuai dengan asas diskresi dan yang mana termasuk suatu perbuatan maladministrasi pemerintah serta memahami akibatnya bagi kepentingan masyarakat. 


\section{DAFTAR PUSTAKA}

\section{A. Buku}

Atmosudirjo, Prajudi S. 1994. Hukum Administrasi Negara. Jakarta: Ghalia Indonesia, Jakarta.

Fajar, A. Muktie dan Yulianto Ahmad.2009. Dualisme Penelitian Hukum Normatif dan Empiris. Yogyakarta: Pustaka Pelajar.

Marbun, S.F. 2012.Hukum Administrasi Negara I. Penerbit: FH UII Press, Yogyakarta. ,\& Mahfud MD. 2006. Pokok-pokok Hukum Administrasi Negara. Yogyakarta: Liberty.

Muchsan.2000. Sistem Pengawasan Terhadap Perbuatan Aparat Pemerintah dan Peradilan Tata Usaha Negara di Indonesia. Yogyakarta: Liberty.

Ridwan, HR. 2010. Hukum Administrasi Negara. Jakarta: Rajawali Pers.

\section{B. Jurnal}

Ansori, Lutfil. Diskresi Pertanggungjawaban Pemerintah dalam Penyelenggaraan Pemerintahan, Jurnal Yuridis, 2015, Vol. 2.

Mustamu, Julista. Diskresi dan Tanggungjawab Administrasi Pemerintahan, Jurnal Sasi, 2011, Vol.17.

\section{Internet}

Lembaga Kajian \& Advokasi Independensi Peradilan, Penjelasan Hukum Asas-Asas Umum Pemerintahan Yang Baik (AUPB) Hukum Administrasi Negara, http://leip.or.id/wp-content/uploads/2016/05/Penjelasan-Hukum-Asas-Asas-Umum-Pemerintahan-yang-Baik-Hukum-Administrasi-Negara.pdf.

Muhammad Ikhwan, Penerapan Asas Diskresi Dalam Pembuatan Keputusan Tata Usaha Negara, http:// studihukum.blogspot.co.id/2010/10/penerapan-asas-diskresi-dalampembuatan.html.

Unpad.ac.id, Mencermati UU Admiistrasi Pemerintahan dan Pertanggungjawaban Hukum Diskresi,http://www.unpad.ac.id/2016/10/mencermati-uu-administrasi-pemerintahan-dan-pertanggungjawaban-hukum-diskresi/.

\section{Peraturan Perundang-Undangan}

Undang-Undang No. 30 Tahun 2014 tentang Administrasi Pemerintahan, Lembaran Negara Republik Indonesia Tahun 2014 Nomor 292, Tambahan Lembaran Negara Republik Indonesia Nomor 5601.

Undang-Undang No. 23 Tahun 2014 Tentang Pemerintahan Daerah, Lembaran Negara Republik Indonesia Tahun 2014 Nomor 244, Tambahan Lembaran Negara Republik Indonesia Nomor 5587.

Undang-Undang No. 5 Tahun 1986 tentang Peradilan Tata Usaha Negara, Lembaran Negara Republik Indonesia Tahun 1986 Nomor 77, Tambahan Lembaran Negara Republik Indonesia Nomor 3344. 